\title{
Agelastica alni L. (Coleoptera:Chrysomelidae) Larvalarının Besin Tüketimi ve Gelişiminde Mikrogıdaların Etkisi
}

\author{
The Effect of Micronutrients on The Development and Food Consumption of Agelastica alni \\ (Coleoptera:Chrysomelidae) Larvae
}

\author{
Mustafa TOKGÖZa, Nurver ALTUN*,b \\ Recep Tayyip Erdoğan Üniversitesi, Fen Edebiyat Fakültesi, Biyoloji Bölümü, 53100, Rize
}

• Geliş tarihi / Received: 06.03.2018 • Düzeltilerek geliş tarihi / Received in revised form: 30.05 .2018 • Kabul tarihi / Accepted: 14.06 .2018

\begin{abstract}
$\ddot{O} z$
Bu çalışmada Agelastica alni larvalarının besin tüketim miktarı ve gelişimi üzerine mikrogıdaların etkisi araştırılmıştır. Larvaların gelişimini inceleyebilmek için pupa kuru ağırlığ süreleri dikkate alınmıştır. Vitamin karışımı (V) ve tuz karışımı (T) konsantrasyonları \%100, \%50 oranlarında artırılarak veya azaltılarak, bazı diyetlerden ise tuz karışımı veya vitamin karışımı çıkarılarak sekiz farklı yapay diyet hazırlanmıştır. Larvalar her bir diyet grubunda teker teker beslenmişlerdir ve 10 tekrar olacak şekilde beslenme deneyleri gerçekleştirilmiştir. Diyetler arasında en fazla tüketim miktarının V/0.5T içeren diyette, en az tüketim miktarının ise $0.5 \mathrm{~V} / \mathrm{T}$ içeren diyette olduğu tespit edilmiştir. Diyetteki tuz konsantrasyonu ile besin tüketimi arasında istatistiksel olarak anlamlı negatif yönlü bir ilişki, vitamin konsantrasyonu arasında ise pozitif yönlü bir ilişki belirlenmiştir. Diyetin tuz ya da vitamin konsantrasyonları ile pupa kuru ağırlığı arasında bir ilişki belirlenememiştir. Tüketim miktarı ile pupa ham protein miktarı arasında ise zayıf bir ilişki tespit edilmiştir. Diyetteki tuz konsantrasyonu pupa lipit miktarını negatif yönde etkilerken, vitamin konsantrasyonu pozitif yönde etkilemektedir. Larvaların farklı diyetlerdeki gelişim süreleri incelendiğinde en uzun larva dönemi V/-T diyetinde beslenen larvalarda, en kısa larva dönemi ise 2V/T diyetinde beslenen larvalarda gözlenmiştir. Diyetin vitamin konsantrasyonu arttıkça gelişim süresinin kısaldığı belirlenmiştir. Gelişim süresi uzadıkça pupa kuru ağırlığı ve pupa lipit miktarı azalmaktadır.
\end{abstract}

Anahtar kelimeler: Agelastica alni, Beslenme, Tuz karışımı, Vitamin, Yapay diyet

\begin{abstract}
In this study, the effect of micronutrients on food consumption and development of Agelastica alni larvae was investigated. The pupa dry weight, the amount of pupa crude protein, the amount of pupa lipid and the developmental periods were taken into consideration in order to examine the development of larvae. Eight different artificial diets were prepared by increasing or decreasing the concentrations of the vitamin mixture (V) and salt mixture (T) by $100 \%$, $50 \%$, and removing the salt mixture or vitamin mixture from some diets. The larvae were fed individually in each dietary group and feeding experiments were performed in 10 replications. It has been determined that the highest consumption of diets is V/O.5T and the lowest consumption is 0.5V/T.A statistically significant negative correlation was found between salt concentration of diet and consumption and a positive correlation was found between vitamin concentrations of diet. A relationship between salt or vitamin concentrations of diet and pupa dry weight has not been established. A weak relationship was found between consumption amount and pupa crude protein amount. The salt concentration of the diet affects the amount of pupa lipid in the negative correlation, while the vitamin concentration affects the positive correlation. When the developmental stages of larvae for different diets were examined, the longest larval period was observed for the larvae fed on the V/-T diet and the shortest larval period was observed for the larvae fed on the 2V/T diet. As the vitamin concentration of the diet increases, the duration of development is shortened. As the length of development increases, the pupa dry weight and pupa lipid amount decrease.
\end{abstract}

Keywords: Agelastica alni, Feeding, Salt mixture, Vitamin, Artificial diet

\footnotetext{
*b Nurver ALTUN; nurver.altun@erdogan.edu.tr; Tel: (0464) 2236126 (dâhili: 1836); orcid.org/0000-0002-2657-9263

${ }^{a}$ orcid.org/0000-0001-7234-5719
} 


\section{Giriş}

Gıda kalitesi; herbivorların büyümesini, gelişmesini, son ağırlıklarını ve üreme başarılarını etkileyen en önemli faktörlerin başında gelir (Gordon, 1968; Genç, 2006; Jensen vd., 2010; Jensen vd., 2012; Barbehenn vd., 2015; Senior vd., 2015). Gida kalitesi protein, karbonhidrat, su, tuz ve vitamin miktarları, sekonder maddeler (tanen, alkaloidler v.b.) gibi birçok faktör tarafindan belirlenir (Genç, 2006; Barbehen vd., 2015).

Mikrogıdalar ya sadece metal iyonundan ibaret ya da metal bağlı inorganik bileşiklerdir (Jose vd., 2014). Vitamin ve tuzlar mikrogidaları oluşturmaktadır. İnsanlarda olduğu gibi tüm hayvanlar büyümek, gelişmek üremek ve hayatlarını sürdürebilmek için diyetlerinde yeterli miktarda vitamin ve tuzlara ihtiyaç duymaktadırlar (Chang vd., 2000; Genç, 2006; Jose vd., 2014). Hücre içi reaksiyonlarda metabolik yolu katalizleyen koenzim olarak görev yaparak hayati rol oynarlar (Chang vd., 2000; Genç, 2006). Birçok Lepidoptera (Kelebekler) üyesinin diyetinde mikrogıdaların bulunması ya da bulunmaması böceklerin davranışlarını ve bağışıklık sistemini etkilemektedir (Jose vd., 2014). Böcekler, diyetlerinden özellikle tiamin, riboflavin, nikotinik asit, piridoksin, pantotenik asit, folik asit ve biotin gibi 7 temel vitamini elde etmek ihtiyacındadırlar (Genç, 2006). Özellikle tuz herbivor böcekler için sınırlayıcı bir etmendir (Trumper ve Simpson, 1993). Bu nedenle hayati fonksiyonları için gerekli potasyum, magnezyum, klor ve fosfat gibi temel mineralleri diyetlerinden alırlar. Demir ve kalsiyum gibi minerallere iz miktarlarda ihtiyaç duyarken potasyum gibi minerallere daha fazla miktarlarda ihtiyaçları olmaktadır (Genç, 2006). Vücutlarında iyon dengesini sağlamak için fizyolojik kontrol mekanizmaları geliştirmişlerdir. Lepidoptera takımı üyelerinin çamur emme davranışları için sodyum iyonu anahtar bir uyarıcidır (Trumper ve Simpson, 1993).

Mikrogıdaların herbivor böceklerin gelişimine etkisiyle ilgili oldukça az sayıda çalışma mevcuttur. Mikrogıdaların böceklerin beslenme davranışları, bağışıklık sistemi, hayatı sürdürebilme ve üreme başarısı üzerine etkileri göz önüne alındığında konu ile ilgili çalışmalar önem kazanmaktadır. Agelastica alni L. Rusya'nın güneyi ve ülkemizde Doğu Karadeniz sahil şeridi boyunca kızılağaç yapraklarıyla beslenerek ağaçlara oldukça fazla zarar veren bir böcek türüdür (Firidin ve Mutlu, 2009). A. alni türünün biyolojisiyle ilgili az sayıda çalışma mevcuttur (Firidin ve Mutlu, 2009; Yanar, 2013). $\mathrm{Bu}$ nedenle çalışmamızda bitkilerin yer yer kurumasına neden olan $A$. alni larvalarının büyüme ve gelişmesine farklı konsantrasyonlarda vitamin ve tuz karışımlarının etkisi incelenmiştir. Zararlı türlerle mücadelede türün biyolojisinin bilinmesi önemlidir. Vitamin ve tuz karışımlarının besin tüketimi ve larvaların gelişimi üzerine olan etkisi belirlenerek elde edilecek veriler türle mücadelede kullanılabilir.

\section{Gereç ve Yöntem}

\subsection{Böcek Kültü̈rünün Yetiştirilmesi}

A. alni yumurtaları 2016 y1lı Mayıs ayında Trabzon ili Kıyıcık beldesindeki kızılağaç (Alnus sp) yaprakları üzerinden toplanarak Recep Tayyip Erdoğan Üniversitesi Zooloji Araştırma Laboratuvarına getirilmiştir. Yumurtalar $25^{\circ} \mathrm{C}$ 'de ve $12 \mathrm{~s}: 12 \mathrm{~s}$ foto periyotta bekletilerek larvaların yumurtadan çıkışı sağlanmış ve daha sonra beslenme deneylerinin gerçekleştirileceği kaplara alınmıştır.

\subsection{Yapay Diyet İçerikleri}

Beslenme deneylerinde Yamamoto (1969) tarafindan geliştirilen yapay diyet içeriğinde değişiklik yapılarak hazırlanan diyetler kullanılmıştır. Diyet içeriğindeki vitamin karışımı (V) ve tuz karışımı (T) konsantrasyonları \%100, $\% 50$ oranlarında artırılarak veya azaltılarak, bazı diyetlerden ise tuz karışımı veya vitamin karışımı çıkarılarak sekiz farklı yapay diyet hazırlanmıştır (Tablo 1). Vitamin karışımı olarak Vanderzant vitamin karışımı (Sigma,V-1007) ve tuz karışımı olarak Wesson's tuz karışımı (Sigma W-1374) kullanılmıştır.

Tablo 1. Yapay diyetlerin vitamin ve tuz karışımı oranlar1

Kullanılan Yapay Diyetlerin Vitamin/Tuz Oranları

\begin{tabular}{c}
\hline $\mathrm{V} / \mathrm{T}$ \\
\hline $0.5 \mathrm{~V} / \mathrm{T}$ \\
\hline $2 \mathrm{~V} / \mathrm{T}$ \\
\hline $\mathrm{V} / 0.5 \mathrm{~T}$ \\
\hline $\mathrm{V} / 2 \mathrm{~T}$ \\
\hline $0.5 \mathrm{~V} / 0.5 \mathrm{~T}$ \\
\hline $\mathrm{V} / \mathrm{T}$ \\
\hline$-\mathrm{V} / \mathrm{T}$ \\
\hline
\end{tabular}

\subsection{Beslenme Deneyleri}

Yumurtadan çıkan A. alni larvaları şeffaf plastik kaplara $(17 \times 12 \times 6$ cm) alınarak beslenme 
deneylerinin gerçekleştirileceği besin tiplerinde tekli besleme kaplarına alınarak her bir besin tipinden 10 tekrar olacak şekilde beslenme deneylerine başlanmıştır. Her besin tipinde verilen günlük besin miktarı ve larva ağırlığ 1 gün aşırı olarak $0.001 \mathrm{~g}$ hassasiyetli terazide tartılmıştır. Tüketilmeden kalan besin miktarı ise üzerinde tarih ve ağırlığı not edilmiş, etiketli alüminyum folyolara sarılarak etüvde kurutulmuştur. Böylece kalan besin miktarı kuru ağırlık olarak hesaplanmıştır.

Beslenme deneyleri larvalar pupa evresine ulaşıncaya kadar devam etmiştir. Larvaların ilk ve son ağırlıkları gelişim performanslarının değerlendirileceği ağırlık kazancının belirlenebilmesi için not edilmiştir. Pupalar, kuru ağırlıklarının belirlenebilmesi için $50^{\circ} \mathrm{C}$ 'deki etüvde sabit ağırlığa erişinceye kadar kurutulmuştur.

\subsection{Kloroform ile Lipit Analizi}

Sabit ağırlığa erişen pupaların depo lipit analizi, pupaların kloroform ile ekstraksiyonuyla belirlenmiştir (Simpson ve Raubenheimer, 2001). Kuru ağırlıkları not edilmiş olan pupaların her biri ağzı kapaklı tüplere konulmuş ve üzerleri geçinceye kadar kloroform ilave edilmiş ve tüplerin kapakları kapatılmıştır. Otomatik çalkalayıcı üzerine yerleştirilen tüplerin 24 saat sonra kapakları açılmış ve tüplerdeki kloroform dökülmüştür. Tüplere yeniden kloroform ilave edilerek bu işlem $3 \mathrm{kez}$ tekrarlanmıştır. Böylece, pupa örneklerinden depo lipit içeriği uzaklaştırılmıştır. Pupalar, $50^{\circ} \mathrm{C}^{\prime}$ deki etüve konularak sabit ağırlığa ulaşıncaya kadar kurutulmuştur. Lipitsiz kuru ağırlıkları da tartılarak pupalardaki depo lipit miktarı hesaplanmıştır.

\subsection{Pupaların Ham Protein Analizi}

Depo lipitleri uzaklaştırılmış olan $A$. alni pupalarının azot miktarı tayini Dumas yönteminin temel alındı $\breve{g} 1$ Thermo Scientific FLASH 2000 Series - NCS Analyzers cihazıyla yapılmıştır (Allen vd., 1986). Bu işlem sonunda bulunan \% $\mathrm{N}$ (Azot) miktarları 6.25 sabitiyle çarpılarak \% ham protein miktarları bulunmuştur (Oonincx vd., 2015).

\section{6. İstatistiksel Analizler}

A. alni larvalarının farklı vitamin ve tuz konsantrasyonları içeren yapay diyetlerdeki tüketim miktarları, pupa kuru ağırlıklarını, pupa

lipit ve pupa ham protein miktarları ve diyetlerdeki gelişim süreleri için normalite testi yapılmıştır. Normal dağılım gösteren tüketim miktarı, kuru pupa ağırlı̆̆ı ve pupa ham protein miktarlarının gruplar arasında farklılık gösterip göstermediğini belirlemek için ANOVA ve ardından TUKEY testi, normal dağılım göstermeyen pupa lipit miktarı ve gelişim süresi değerlerinin gruplar arasındaki farklılığını belirlemek için Kruskal Wallis ve ardından Man Whitney U testi yapılmıştır. Bu testler için SPSS 23 versiyonu kullanılmıştır.

\section{Bulgular}

Farklı diyetlerde beslenen A. alni larvalarının tüketim miktarları Şekil 1'de görülmektedir. Larvaların tüketim miktarları incelendiğinde en fazla tüketim miktarının V/0.5T içeren diyette, en az tüketim miktarının ise $0.5 \mathrm{~V} / \mathrm{T}$ içeren diyette olduğu tespit edilmiştir. Korelasyon testi sonuçlarına göre diyetteki tuz konsantrasyonu ile besin tüketimi arasında istatistiksel olarak anlamlı negatif yönlü bir ilişki belirlenmiştir $(\mathrm{r}=-0.71$, $\mathrm{p}<0.01$ ). Ayrica 8 grupla yapılan ANOVA testi sonuçlarına göre; tüketim miktarı bakımından gruplar arasında önemli farkl1lık olduğu tespit edilmiştir (ANOVA F=12.24; $\mathrm{p}<0.01$ ).

TUKEY testi sonuçlarına göre; V/-T diyeti ile $\mathrm{V} / 0.5 \mathrm{~T}$ diyeti arasında önemli bir farklılık görülmemiştir $(\mathrm{p}>0.05) \quad($ Tablo 2). Diyetteki vitamin konsantrasyonu ile tüketim miktar1 arasında pozitif yönlü bir ilişki olduğu belirlenmiştir $(r=0.69, p<0.01)$. Ayrıca TUKEY testi sonuçlarına göre $-\mathrm{V} / \mathrm{T}$ diyetindeki tüketim miktarı 2V/T diyetindeki tüketim miktarından farklılık göstermemektedir ( $>0.05$ ) (Tablo 2).

Tablo 2. Farkl1 diyetlerde beslenen Agelastica alni larvalarının tüketim miktarı ve pupa ham protein miktarları ve TUKEY testi sonucu

\begin{tabular}{|c|c|c|}
\hline Besin Tipi & $\begin{array}{l}\text { Tüketim Miktarı } \\
(\mathrm{mg}) \\
\text { (Ortalama } \pm \text { Standart } \\
\text { Hata) }\end{array}$ & $\begin{array}{l}\text { Pupa Ham Protein } \\
\text { Miktarı (mg) } \\
\text { (Ortalama } \pm \text { Standart } \\
\text { Hata) }\end{array}$ \\
\hline $\mathrm{V} / \mathrm{T}$ & $37.76 \pm 1.05^{\mathrm{bcd} *}$ & $1.51 \pm 0.09^{\mathrm{ab}}$ \\
\hline $0.5 \mathrm{~V} / \mathrm{T}$ & $32.12 \pm 1.19^{\mathrm{a}}$ & $1.34 \pm 0.09^{\mathrm{a}}$ \\
\hline $2 \mathrm{~V} / \mathrm{T}$ & $42.00 \pm 1.62^{\mathrm{de}}$ & $1.90 \pm 0.15^{b}$ \\
\hline $\mathrm{V} / 0.5 \mathrm{~T}$ & $43.85 \pm 1.56^{\mathrm{e}}$ & $1.62 \pm 0.05^{\mathrm{ab}}$ \\
\hline $\mathrm{V} / 2 \mathrm{~T}$ & $33.98 \pm 0.58^{\mathrm{ab}}$ & $1.47 \pm 0.10^{\mathrm{ab}}$ \\
\hline $0.5 \mathrm{~V} / 0.5 \mathrm{~T}$ & $35.43 \pm 1.23^{\mathrm{abc}}$ & $1.47 \pm 0.10^{\mathrm{a}}$ \\
\hline $\mathrm{V} / \mathrm{-T}$ & $42.19 \pm 0.72^{\mathrm{de}}$ & $1.50 \pm 0.07^{\mathrm{ab}}$ \\
\hline$-\mathrm{V} / \mathrm{T}$ & $39.41 \pm 1.36^{\mathrm{cd}}$ & $1.30 \pm 0.11^{\mathrm{a}}$ \\
\hline
\end{tabular}


Tablo 3. Farklı diyetlerde beslenen Agelastica alni larvalarının pupa kuru ağırlığ miktarı, gelişim süreleri ve Man Whitney U testi sonucu

\begin{tabular}{|c|c|c|c|}
\hline $\begin{array}{l}\text { Besin } \\
\text { Tipi }\end{array}$ & $\begin{array}{l}\text { Pupa } \\
\text { Kuru } \\
\text { Ağırlığ } \\
\text { (Ortalama } \\
\pm \text { Standart } \\
\text { Hata) } \\
\end{array}$ & $\begin{array}{l}\text { Pupa Lipit } \\
\text { Miktarı } \\
(\mathrm{mg}) \\
\text { (Ortalama } \\
\pm \text { Standart } \\
\text { Hata) } \\
\end{array}$ & $\begin{array}{l}\text { Gelişim Süresi } \\
\text { (gün) (Ortalama } \\
\pm \text { Standart Hata) }\end{array}$ \\
\hline $\mathrm{V} / \mathrm{T}$ & $2.92^{\mathrm{a}^{*}}$ & $0.82^{\mathrm{a}}$ & $16.6 \pm 0.92^{\mathrm{a}}$ \\
\hline $0.5 \mathrm{~V} / \mathrm{T}$ & $2.87^{\mathrm{ab}}$ & $0.65^{\mathrm{a}}$ & $11.5 \pm 0.67^{b}$ \\
\hline $2 \mathrm{~V} / \mathrm{T}$ & $3.64^{\mathrm{c}}$ & $1.06^{\mathrm{d}}$ & $8.7 \pm 0.47^{\mathrm{c}}$ \\
\hline $\mathrm{V} / 0.5 \mathrm{~T}$ & $2.73^{b}$ & $0.76^{\mathrm{a}}$ & $11.9 \pm 1.14^{\mathrm{bc}}$ \\
\hline $\mathrm{V} / 2 \mathrm{~T}$ & $2.30^{b}$ & $0.3^{\mathrm{c}}$ & $16.4 \pm 0.65^{\mathrm{a}}$ \\
\hline $0.5 \mathrm{~V} / 0.5 \mathrm{~T}$ & $2.75^{\mathrm{a}}$ & $0.79^{\mathrm{a}}$ & $8.9 \pm 0.35^{\mathrm{c}}$ \\
\hline $\mathrm{V} / \mathrm{-T}$ & $2.64^{\mathrm{a}}$ & $0,61^{b}$ & $22.7 \pm 0.78^{\mathrm{d}}$ \\
\hline$-\mathrm{V} / \mathrm{T}$ & $3.24^{\mathrm{a}}$ & $0.75^{b}$ & $14.8 \pm 0.25^{\mathrm{a}}$ \\
\hline
\end{tabular}

*Harfler, gruplar arasındaki farklılı̆̆ göstermektedir $(\mathrm{p}<0,05)$

En fazla pupa kuru ağırlığ $2 \mathrm{~V} / \mathrm{T}$ diyetinde, en düşük ağırlık ise $\mathrm{V} / 2 \mathrm{~T}$ diyetinde beslenen larvaların pupalarında gerçekleşmiştir (Şekil 2). $2 \mathrm{~V} / \mathrm{T}$ diyetiyle beslenen larvaların tüketim miktarlarının yüksek olduğu, V/2T diyetinde beslenen larvaların tüketim miktarının da düşük olduğu görülmektedir (Tablo 2). Korelasyon testi sonucunda pupa kuru ağırlığı ile diyetteki tuz ve vitamin konsantrasyonları arasında bir ilişki tespit edilememiştir. Farklı diyetlerdeki tüketilen gidaların larvalar tarafından kullanılabilirliği incelendiğinde pupa ham protein miktarının en fazla 2V/T diyetinde beslenen larvalarda, en düşük miktarın ise $-\mathrm{V} / \mathrm{T}$ diyetinde beslenen larvalarda olduğu tespit edilmiştir (Tablo 2, Şekil 4). Tüketim miktarı ile pupa ham protein miktarı arasında bir ilişki tespit edilememiştir. Pupa kuru ağırlığ 1 ile pupa ham protein miktarı arasında ise pozitif yönde zayıf bir ilişki vardır $(\mathrm{r}=0.44$, $\mathrm{p}<0.001)$. Diyetin vitamin konsantrasyonu ile pupa toplam protein miktarı arasında da bir ilişki tespit edilmiştir $(\mathrm{r}=0.564, \mathrm{p}<0.001)$. Ayrıca tüketilen vitamin konsantrasyonunun pupa ham protein miktarını etkilediği belirlenmiştir ( $\mathrm{r}=0.47$, $\mathrm{p}<0.001)$. Fakat, diyetteki tuz konsantrasyonu ya da tüketilen tuz miktariyla pupa ham protein miktarı arasında bir ilişki tespit edilememiştir.



Şekil 1. Farklı diyetlerde beslenen Agelastica alni larvalarının tüketim miktarı

Pupa lipit miktarı incelendiğinde, en yüksek değerin 2V/T diyetinde beslenen larvaların pupalarında, en düşük değerin ise $\mathrm{V} / 2 \mathrm{~T}$ diyetinde beslenen larvaların pupalarında olduğu belirlenmiştir (Şekil 3). Pupa lipit miktarı bakımından 8 farklı grupla yapılan Kruskal Wallis testi anlamlı sonuç vermiştir ve Man Whitney U testi sonuçlarına göre $2 \mathrm{~V} / \mathrm{T}$ diyetinde beslenen larvalarla $\mathrm{V} / 2 \mathrm{~T}$ diyetinde beslenen larvaların pupa lipit değerleri birbirinden farkl11ık göstermektedir (Tablo 3). Korelasyon testi sonuçlarına göre ise larvaların tüketim miktarının pupa lipit miktarını zayıf da olsa etkilediği belirlenmiştir $(\mathrm{r}=0.30$; $\mathrm{p}<0.001)$. Pupa kuru ağırlığı ile pupa lipit miktarı 
arasında da bir korelasyon olduğu belirlenmiştir $(\mathrm{r}=0.54, \quad \mathrm{p}<0.001)$. Ayrica tüketilen vitamin miktarı pupa lipit miktarını zayıf da olsa etkilemektedir $(r=0,29, p<0,005)$. Fakat, tüketilen tuz miktarıyla pupa lipit miktarı arasında bir korelasyon tespit edilememiştir. Korelasyon testi sonuçlarına göre hem diyetlerin vitamin konsantrasyonunun $(\mathrm{r}=0.5, \mathrm{p}<0.001)$ hem de tuz konsantrasyonunun $(\mathrm{r}=-0.47 ; \mathrm{p}<0.001)$ pupa lipit miktarını etkilediği belirlenmiştir. Fakat tuz konsantrasyonu ile pupa lipit miktarı arasinda negatif yönde bir ilişki mevcuttur $(\mathrm{r}=-0,47$; $\mathrm{p}<0,01)$.

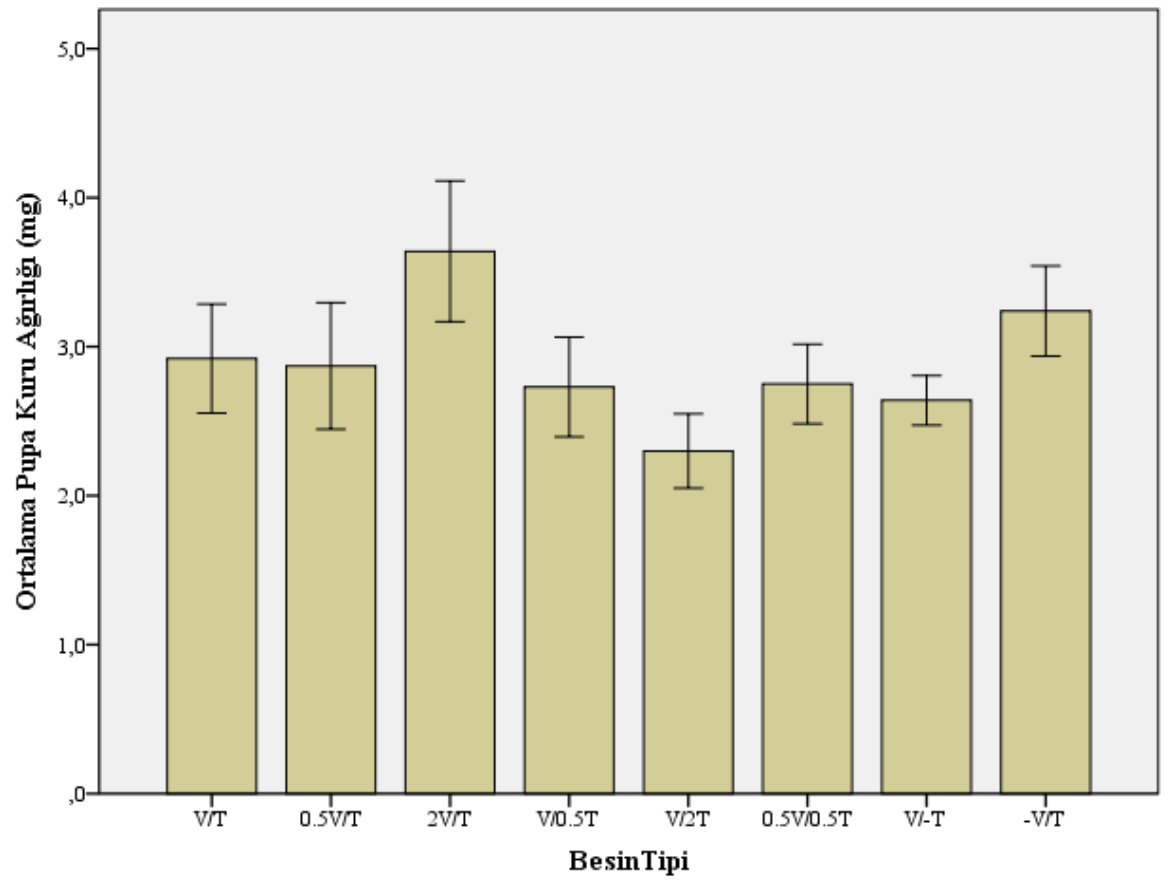

Şekil 2. Farklı diyetlerde beslenen Agelastica alni larvalarının pupa kuru ağırlıkları

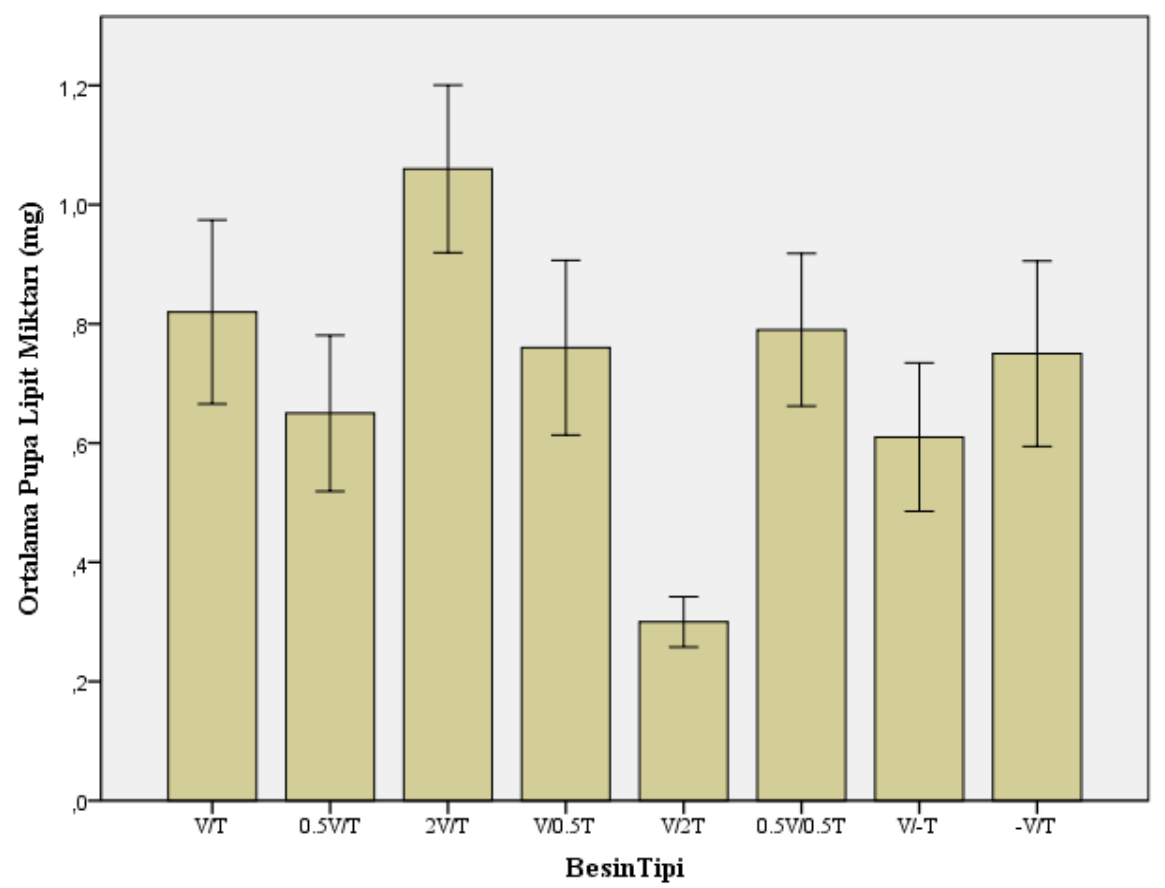

Şekil 3. Farklı diyetlerde beslenen Agelastica alni larvalarının pupa lipit miktarları (mg) 


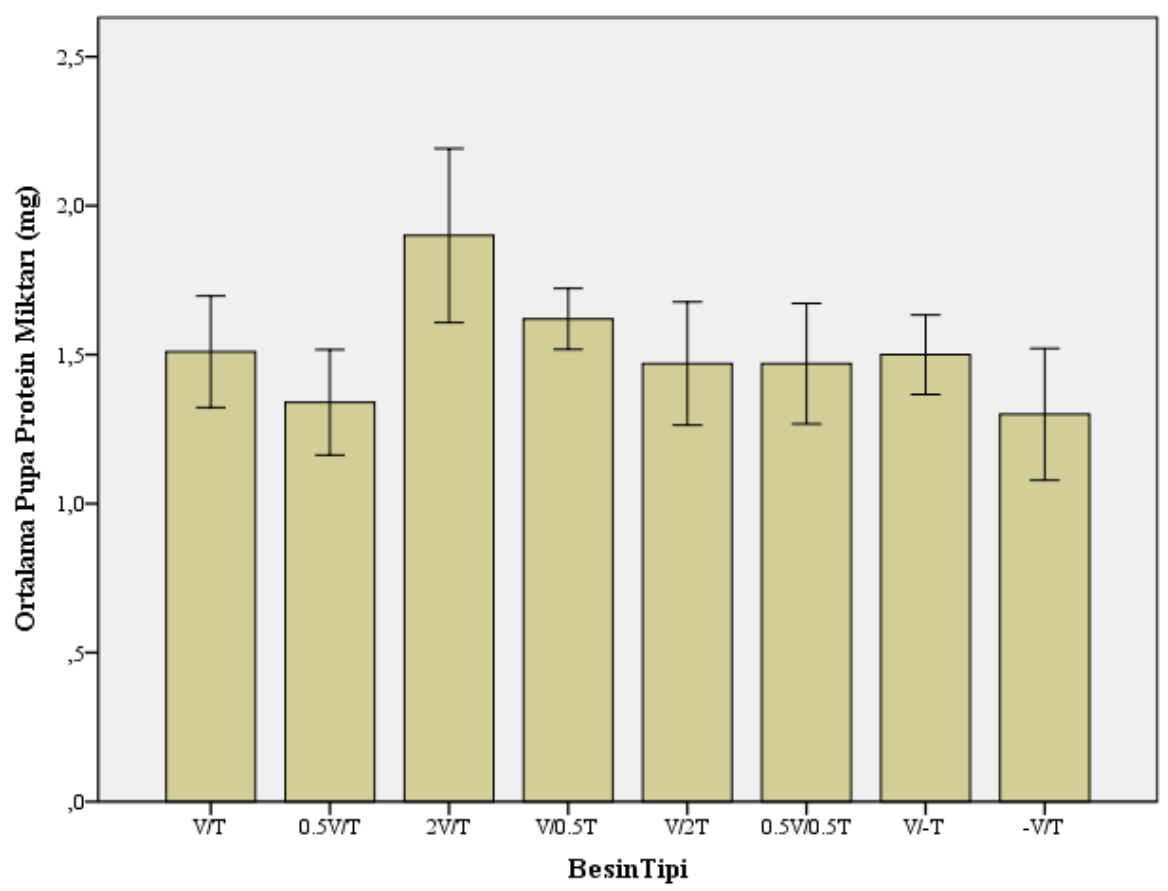

Şekil 4. Farklı diyetlerde beslenen Agelastica alni larvalarının pupa ham protein miktarları (mg)

Larvaların farklı diyetlerdeki gelişim süreleri incelendiğinde en uzun larva dönemi V/-T diyetinde beslenen larvalarda, en k1sa larva dönemi ise $2 \mathrm{~V} / \mathrm{T}$ diyetinde beslenen larvalarda gözlenmiştir (Şekil 5). İlginç olan husus 2V/T diyetinde beslenen larvaların gelişim süresiyle $0.5 \mathrm{~V} / 0.5 \mathrm{~T}$ ve $\mathrm{V} / 0.5 \mathrm{~T}$ diyetinde beslenen larvaların gelişim süreleri birbirlerinden farkl1l1k göstermemektedir (Tablo 3) ve diyetlerin vitamin konsantrasyonu ile gelişim süresi arasında negatif yönde bir korelasyon belirlenmiştir $(\mathrm{r}=-0.51$, $\mathrm{p}<0.001)$. Ayrıca gelişim süresi uzadıkça pupa kuru ağırlıkları $(\mathrm{r}=-0.415, \mathrm{p}<0.001)$ ve pupa lipit miktarlarının $(\mathrm{r}=-0.329, \mathrm{p}<0.05)$ azalmaktadır.

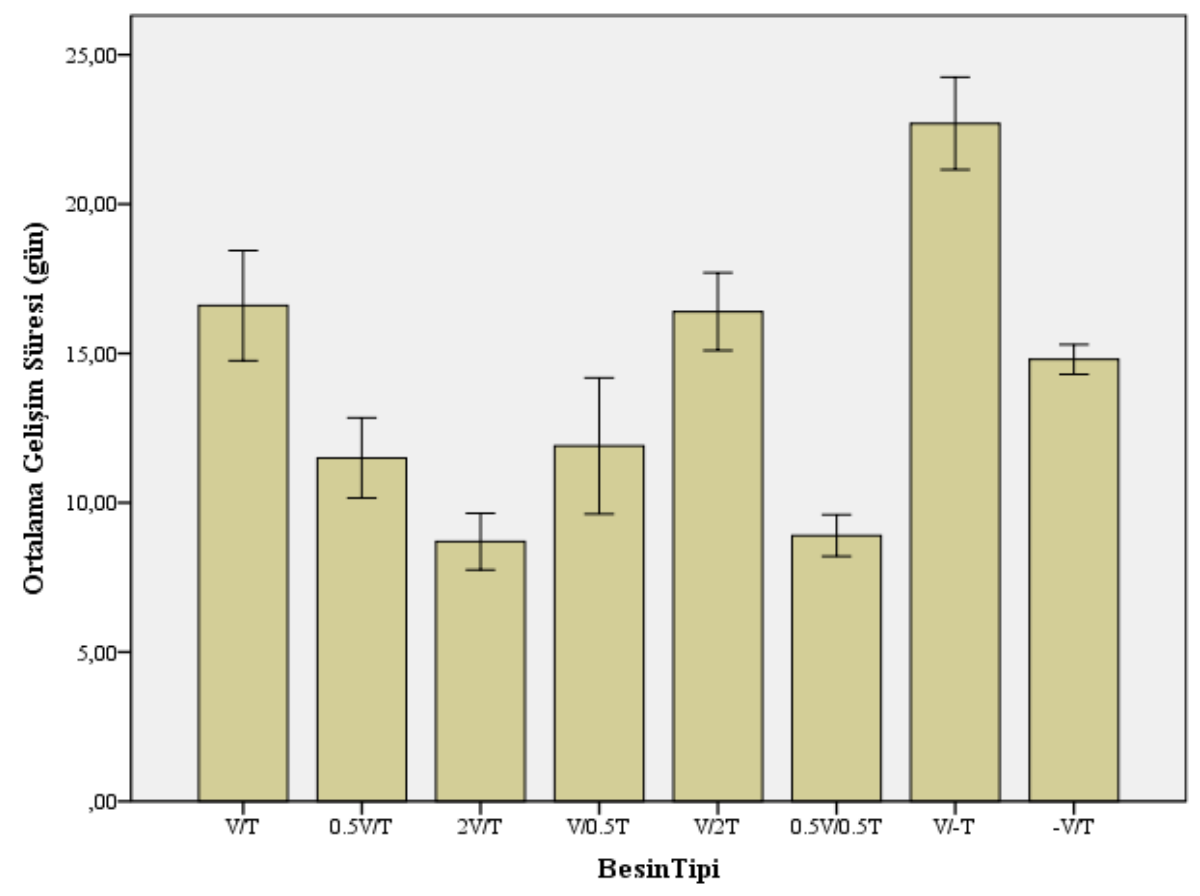

Şekil 5. Farklı diyetlerde beslenen Agelastica alni larvalarının gelişim süreleri (gün) 


\section{Tartışma ve Sonuç}

$\mathrm{Bu}$ çalışmada en fazla tüketim miktarı $\mathrm{V} / 0.5 \mathrm{~T}$ diyetinde beslenen larvalarda, en az tüketim miktar ise $0.5 \mathrm{~V} / \mathrm{T}$ diyetinde beslenen larvalarda tespit edilmiştir. V/2T diyetindeki tüketim miktarı da $0.5 \mathrm{~V} / \mathrm{T}$ diyetinden farkl1lık göstermemektedir. Diyetteki tuz konsantrasyonunun artışıla larvaların tüketim miktarı azalmaktadır. Çünkü, tuzlar farklı konsantrasyonlarda herbivor saldırılarına karşı caydırıcı etki göstermektedir. Tuzlar, hayvanların yaşamı devam ettirmesinde oldukça önemli rol oynayan beslenmede temel rol oynamaktadırlar. Bir besinin kabul edilebilirliği sürecinde tat reseptörlerinin görevini yerine getirebilmesinde temel maddelerdir. Düşük konsantrasyonlarda hayvanlar için gerekli fakat yüksek konsantrasyonlarda zararlı olabilirler (Pontes vd., 2017). LoPresti (2014), Chenopodiaceae familyasındaki bitki türlerinin tuz keseciklerinin Platyprepia virginalis, Heliothis virescens, Diabrotica undecimpunctata türlerine karşı caydırıcı olduğunu tespit etmişlerdir. Böceklerde belirli tuzları algılayan tat reseptörleri beslenmede fagostimulant olarak önemli rol oynamaktadır. Schoonhoven vd. (1992), düşük konsantrasyonda tuzların et sineklerinin tuz reseptörlerini uyardığı fakat yüksek konsantrasyonlarda caydırıcı olduğunu belirtmişlerdir. Tuz yoksunluğu bitkinin daha az tercih edilmesine neden olabilir. Tuz tek başına beslenme caydırıcısı olarak da görev yapabilir (Trumper ve Simpson, 1993). Deletre vd. (2016), böceklerde yüksek tuz konsantrasyonu ve acılığın aynı reseptör tarafından uyarıldığını ileri sürmüşlerdir. Acılık ve yüksek tuz konsantrasyonu böcekler için beslenme engelleyicisidir. Dolayısıyla tuz konsantrasyonu miktarı besinin kabul edilebilirliğinde oldukça önemlidir. Pontes vd. (2017), tuz yoksunluğunun böceklerin besini reddetmesine neden olabileceğini ileri sürmektedir. Çalışmamızda ise A. alni larvaları tuzun olmadığı diyeti oldukça fazla miktarda tüketmiştir. $\mathrm{Bu}$ durum, vitamin karışımlarının besin tüketimi üzerindeki olumlu etkisinden kaynaklanabilir. Etebari ve Matindoost (2005), Bombyx mori ile yapmış oldukları çalışmada diyetteki vitamin miktarının türün tüketim miktarını artırdığını belirlemişlerdir.

En fazla pupa kuru ağırlığı 2V/T diyetinde beslenen larvaların pupalarında, en düşük pupa kuru ağırlığı ise $\mathrm{V} / 2 \mathrm{~T}$ diyetinde beslenen larvalarda tespit edilmiştir. En düşük pupa kuru ağırlığının $\mathrm{V} / 2 \mathrm{~T}$ diyetinde olmasının nedeni tüketim miktarının da ilgili diyette az olmasından kaynaklanabilir V/2T diyetinde beslenen larvaların pupalarında pupa lipit miktarının da en az miktarda olması bu sonucu desteklemektedir. Tuz konsantrasyonu ile pupa lipit miktarı ters ilişkilidir. Bunun nedeni tuz konsantrasyonunun tüketim miktarını olumsuz etkilemesi ve larvaların az tüketim miktarından dolayı pupa kuru ağırlığının ve lipit miktarının az oluşundan kaynaklanabilir. En fazla pupa kuru ağırlığının görüldüğü $2 \mathrm{~V} / \mathrm{T}$ diyetinde pupa lipit ve pupa ham protein miktarlarının da en fazla miktarda oluşu tüketilen besinlerin larvalar tarafından biyokütleye dönüştürüle-ildiğini göstermektedir. Çalışmamizda diyetteki vitamin konsantrasyonunun pupa lipit ve ham protein miktarlarını pozitif yönde etkilediği ve tüketilen vitamin miktarının da pupa lipit miktarını etkilediği belirlenmiştir. İlginç olan durum, tüketilen vitamin miktarı ya da diyetin vitamin konsantrasyonuyla pupa kuru ağıllığı arasında bir ilişkinin tespit edilememesidir. Bombyx mori ve Ceratitis capitata türleri ile yapılan çalışmalar diyetteki vitamin konsantrasyonunun belirli bir konsantrasyona kadar pupa kuru ağırlığını olumlu yönde etkilediğini (Chang ve Li, 2004; Etebari ve Matindoost, 2005), belirli bir konsantrasyondan sonra ise pupa kuru ağırlığının azaldığını (Etebari ve Matindoost, 2004) ortaya koymuştur. A. alni türünde ise diyetin vitamin konsantrasyonu pupa kuru ağırlığını etkilememektedir. Vitaminler, böceklerde spesifik metabolik reaksiyonlar ve gelişim için gerekli olan bileşenlerdir (Ahsan vd., 2013). Baz1 vitaminler besinlerin sindirilebilirliğini ve vücutta kullanılabilirliğini artırır (Etebari ve Matindoost, 2005). Dolayisıyla A. alni larvalarında diyetteki vitamin konsantrasyonunun artışıla gidaların kullanılabilirliği artmış olabilir. Böylece, vitamin konsantrasyonuyla birlikte pupa ağırlığında istatistiksel olarak anlamlı bir artı̧̧ gözlenmese de diyetten alınan gidalar daha fazla kullanılabilir hale gelmiş, pupa lipit ve ham protein miktarlarında da artış gözlenmiş olabilir.

A. alni larvalarında diyetteki vitamin konsantrasyonu arttıkça gelişim süresinin azaldığ 1 tespit edilmiştir. Ayrıca gelişim süresi uzadıkça pupa kuru ağırlığı ve pupa lipit miktarında da düşüş kaydedilmiştir. Wang vd. (2014), Cnaphalocrocis medinalis larvalarının vitamin eksikliğinde gelişemediğini belirtmiştir. Gelişim süresi diyetteki gıdaların kullanılabilirliğiyle ilişkilidir. Sonuç olarak, A. alni larvaları için vitamin besinlerin sindirilebilirliğini ve kullanılabilirliğini artırdığından diyetteki vitamin konsantrasyonu arttıkça gelişim süresi kısalmakta ve buna bağlı olarak da pupa kuru ağırlığ 1 ve pupa ham protein miktarları da artış göstermektedir. 


\section{Katkı Belirtme}

Bu çalışma Mustafa TOKGÖZ'ün Yüksek Lisans tezinden üretilmiştir.

\section{Kaynaklar}

Ahsan, MK., Khan, A.R. ve Ferdous, T., 2013. Growth and development of the mulberry silkworm, Bombyx mori L. on vitamin B and $\mathrm{C}$ supplemented diet. Bangladesh Journal of Zoology, 41(2), 199-206.

Allen, S.E., Grimshaw, H.M., Parkinson, J.A., Quarmby, C. ve Roberts, J.D.,1986. Chemical Analysis, in: Champman, S.B. (Ed), Methods in plant Ecology, Oxford, Blackwell Scientific Puplications., pp. 411466.

Barbehenn, R.V., Knister, J., Marsik, F., JahantMiller, C. ve Nham, W., 2015. Nutrients are assimilated efficiently by Lymantria dispar caterpillars from the mature leaves of trees in the Salicaceae. Physiological Entomology, 40, 72-81.

Chang, C.L ve Li, Q.X., 2004. Dosage effects between dietary niacin and other B vitamins on larval development of Ceratitis capitata (Diptera: Tephritidae). Annals of The Entomological Society of America, 97(3), 536-540.

Chang, C.L., Kurashima, R. ve Albrecht, C., 2000. Effect of limiting concentrations of growth factors in mass rearing diets for Ceratitis capitata larvae (Diptera: Tephritidae). Annals of The Entomological Society of America, 93(4), 898-903.

Deletre, E., Schatz, B., Bourguet, D., Chandre, F., Williams, L., Ratnadass, A. ve Martin, T., 2016. Prospects for repellent in pest control: current developments and future challenges. Chemoecology, 26, 127-142.

Etebari, K. ve Matindoost, L., 2004. Effects of hypervitaminosis of vitamin B3 on silkworm biology. Journal of Biosciences, 29(4), 417-422.

Etebari, K. ve Matindoost, L., 2005. Application of multi-vitamins as supplementary nutrients on biological and economical characteristics of silkworm Bombyx mori L. Journal of Asia-Pasific Entomology, 8(1), 107-112.
Firidin, B. ve Mutlu, C., 2009. Nitrogen utilization pattern and degradation capability of some plant secondary metabolites by Agelastica alni L. (Coleoptera: Chrysomelidae). Journal of Entomological Research Society, 11(2), 115.

Genç, H., 2006. General principles of insect nutritional ecology. Trakya University Journal of Natural Sciences, 7(1), 53-57.

Gordon, H.T., 1968. Quantitative aspects of insect nutrition. American Zoologist, 8, 131-138.

Jensen, K., Mayntz, D., Toft, S., Clissold, F.J., Hunt, J. Raubenheimer, D. ve Simpson, S.J., 2012. Optimal foraging for specific nutrients in predatory beetles. Proceedings of The Royal Society B / Biological Sciences, 279, 2212-2218.

Jensen, K., Mayntz, D., Wang, T., Simpson, S.J., ve Overgaad, J., 2010. Metabolic consequences of feeding and fasting on nutritionally different diets in the wolf spider Pardosa prativaga. Journal of Insect Physiology, 56, 1095-1100.

Jose, B.K., Sudheendrakumar, V.V. ve Sajeev, T.V., 2014. Micronutrients - Significance and function in growth and survival of insects - A case study. Entomology and Applied Science Letters, 1(3), 1-4.

LoPresti, E.F., 2014. Chenopod salt bladders deter insect herbivores. Oecologia, 174, 921-930.

Oonincx, D.A.G.B., van Broekhoven, S. van Huis, A. ve van Loon, J.J.A., 2015. Feed conversion, survival and development and composition of four insect species on diets composed of food by-products. PLoS One, 10(12), 1-20.

Pontes, G., Pereira, M.H. ve Barrozo, R.B., 2017. Salt controls feeding decisions in a bloodsucking insect. Journal of Insect Physiology, 98, 93-100.

Schoonhoven, L.M., Blaney, W.M. ve Simmonds, M.S.J., 1992. Sensory coding of feeding deterrents in phytophagous insects, in: Bernays, E.A. (Ed), Insect-Plant Interactions, Boca Raton, FL: CRC, 4, 5979. 
Senior, A.M., Charleston, M.A., Lihoreau, M., Buhl, J., Raubenheimer, D. ve Simpson, S.J., 2015. Evolving nutritional strategies in the presence of competition: A geometric agent based model. PLOS Computational Biology, 11, 3, 1-24.

Simpson, S.J. ve Raubenheimer, D., 2001. The geometric analysis of nutrientallelochemical interactions: a case study using locusts. Ecology, 82, 422-439.

Trumper, S. ve Simpson, S.J., 1993. Regulation of salt intake by nymphs of Locusta migratoria. Journal of Insect Physiology, 39(10), 857-864.
Wang, Y.C., Zhang, S.K., Ren, X.B. ve Su, J., 2014. Effects of dietary additives in artificial diets on survival and larval development of Cnaphalocrocis medinalis (Lepidoptera: Crambidae). Florida Entomologist Society, 97(3), 1041-1048.

Yamamoto, R. T., 1969. Mass rearing of tobacco hornworm. II. Larval rearing and pupation. Journal of Economic Entomology, 62, 1427-1431.

Yanar, O., 2013. Agelastica alni (L.) (Coleoptera: Chrysomelidae) Larvalarının Beslenme ve Gelişimine Besin Kalitesi ve Tanik Asitin Etkisi. Karadeniz Fen Bilimleri Dergisi/The Black Sea Journal of Sciences, 3(9), 81-90. 